\title{
O wartościach w świetle swobodnych wypowiedzi uczniów. Przestrzeń aksjologicznego projektowania sytuacji lekturowej
}

\author{
Values in relation to student's open interpretations. \\ The space of the axiological design of the reading \\ situation
}

\author{
|Paweł Sporek
Uniwersytet Pedagogiczny im. KEN w Krakowie
}

\begin{abstract}
The following text concerns values revealated in free student's opinions. The first point of reference for the issue mentioned above was to search for the axiological image of young generation. The second point of reference is the presence of values in the teaching of the Polish literature and language. Further part of the text describes the concept of planning the lesson based on the use of students' opinions (open interpretations), which if organised in a planned and conscious way, could stimulate students' participation and facilitate reading while dealing with literature discussed at school. Materials obtained this way show the axiological thinking of young people. The way the axiological thinking of young people mentioned in the topic has been discussed in reference to the exemplifying material, which constituted the record of student's opinions gathered during Polish language classes regarding the very first reception of a literary text chosen for discussion. These selected cultural texts are: The Old Man and the Sea by Ernest Hemingway, Córka czarownic by Dorota Terakowska and Troy directed by Wolfgang Petersen. In the conclusion the author drew attention to the importance of free student's statements for cultural and literary education and to discover the axiological diagnoses of students.
\end{abstract}

Key words: education, open interpretation, values, reception

Streszczenie: Tekst artykułu skupia się wokół zagadnienia wartości, które ujawniają się w swobodnych wypowiedziach uczniowskich. Jego pierwsza część ogniskuje się wokół badań nad aksjologią wśród uczniów. Druga odnosi kwestie związane z wartościami do problemów dydaktyki literatury. Dalsza część artykułu opisuje koncepcję wykorzystania swobodnych wypowiedzi uczniowskich dla potrzeb kształcenia kulturowo - literackiego oraz służy prezentacji świata rozpoznań aksjologicznych, które ujawniają się w konfrontacji uczniów z rozmaitymi tekstami kultury. Na potrzeby niniejszego artykułu zaprezentowane zostały uczniowskie świadectwa odbioru takich dzieł jak Stary człowiek i morze Ernesta Hemingwaya, Córka czarownic Doroty Terakowskiej oraz filmu Troja w reżyserii Wolfganga Petersena. W zamknięciu tekstu autor zwraca uwagę na rolę i znaczenie tak organizowanych swobodnych wypowiedzi dla odkrywania uczniowskich sposobów wartościowania świata oraz realizacji założeń kształcenia kulturowo-literackiego.

Słowa kluczowe: edukacja, swobodne wypowiedzi, wartości, recepcja 
Aksjologia w przestrzeni szkolnej funkcjonuje w rozmaity sposób: na poziomie deklaracji wpisanych w podstawę programową, programy nauczania, podręczniki szkolne; w obrębie rozpoznań na konkretnych lekcjach, w aktach analiz i interpretacji tekstów kultury oraz namyśle nad językiem i jego rolą $\mathrm{w}$ procesie wartościowania; urzeczywistnia się $\mathrm{w}$ nauczycielskich i uczniowskich wyborach, które wyrażają się w stosunkach i relacjach międzyludzkich zachodzących przecież nie tylko w murach szkoły. Pierwszy zasygnalizowany aspekt nie zostanie uwzględniony w niniejszych rozważaniach ze względu na określone założenia teleologiczne i metodologiczne niniejszego tekstu ${ }^{1}$. Pominę także punkt trzeci ze względu na swoją badawczą nieweryfikowalność, jednostkowość i niepowtarzalność. Przedmiotem niniejszego tekstu będzie wymiar rozpoznań aksjologicznych powiązanych z lekturą szkolną, jej opracowaniem lekcyjnym, a ściślej - z fazą wstępną pracy nad wybranym dziełem literackim czy tekstem kultury. Będą ją stanowić swobodne wypowiedzi uczniów (klas gimnazjalnych) na temat czytanych przez nich utworów i obejrzanego filmu oraz komentarze wyjaśniające, które posłużą również jako materiał egzemplifikacyjny.

\section{O wartościach dojrzewającej młodzieży - zarys perspektywy badawczej}

Obraz aksjologiczny młodych ludzi w badaniach ostatnich dwudziestu kilku lat jest mocno niejednorodny. Badania prowadzone przez m.in. Hannę Świdę-Ziembę (Świda-Ziemba 1998; 2005), Mirosława Szymańskiego (Szymański 1998), Ryszarda Jedlińskiego (Jedliński 2000), Kazimierza Denka (Denek 2000) czy stosunkowo niedawno przez Małgorzatę Karwatowską (Karwatowska 2012), Magadalenę Kleszcz i Małgorzatę Łączyk (Kleszcz, Łączyk 2014) przekonują, że trudno znaleźć wiele wspólnych mianowników dla rozpoznań dokonanych wśród młodzieży. Charakterystyczna jest stosunkowo wyraźna niespójność aksjologiczna, a także dychotomia w spojrzeniu na otaczający młodych ludzi świat wartości. Tym, co względnie stałe, jest wysoka pozycja wartości takich jak rodzina czy przyjaźń, względnie wysoka - miłości. Ważna jest także praca, status społeczny, zawodowy sukces. Widoczny jest upadek wartości o charakterze religijnym oraz dystans do dobra czy prawdy. Taki obraz aksjologii młodych ludzi związany jest ze zmieniającym się kontekstem społeczno-kulturowym, rozwojem cywilizacji, silnym wpływem mediów, które propagują wartości hedonistyczne i materialne oraz powierzchownie rozumiane jakości witalne i estetyczne (Sporek 2016, 72-77). Swoisty kryzys aksjologiczny, wynikający ze sytuacjonizmu i światopoglądowego pluralizmu, to jeden z wyznaczników dominującego modelu kultury ponowoczesnej (Wagner 2005, 20-21). W zarysowaną wyżej sytuację wpisuje się refleksja o wyborach wartości przez młodych ludzi. Myślenie o aksjologii w odniesieniu do dorastającej i dojrzewającej

\footnotetext{
${ }^{1}$ Kwestiom tym, w odniesieniu do dokumentów ministerialnych, podręczników i programów na poziomie gimnazjalnym, poświęciłem książkę: Przestrzeń aksjologiczna $w$ wybranych podręcznikach gimnazjalnych do kształcenia literacko-kulturowego (1999 - 2005), 2016, Kraków.
} 
młodzieży jest ważne, ale też trudne. Maria Jędrychowska, pisząc o wieku gimnazjalnym, zauważała, że jest to czas bardzo istotny dla formowania się osobowości. Wiąże się zarówno z buntem, jak i narodzinami myślenia o poważnym, przyszłym życiu, zaznawaniem pierwszych sympatii i miłości. Jest „okresem wpisywania się w wybierany system wartości, a więc budowania własnej kultury aksjologicznej, okresem formowania siebie" (Jędrychowska 2002, 82).

Rozpoznania aksjologiczne na języku polskim mogą ujawniać się w rozmaitych ogniwach lekcji. Można postawiać tezę, że wpływ na ich uzewnętrznienie mogą mieć stosowane metody i formy pracy, indywidualne właściwości nauczyciela oraz dyspozycje członków zespołu uczniowskiego, a także różnorodne materiały wykorzystywane na lekcji. Niewątpliwie projektowanie kształcenia w duchu myślenia antropocentrycznego, szanującego podmiotowość nauczycieli i uczniów, wspiera myślenie o wartościach moralnych bardziej niż edukacja organizowana wokół przemian procesu historycznoliterackiego czy zakładająca konfrontację z dziełami literatury traktowanymi jako artystyczne egzemplifikacje porządku teoretycznoliterackiego. Powyższe uwarunkowania, obejmujące zależności między edukacją ukierunkowaną aksjologicznie a metodyką języka polskiego, mające swoje umocowanie w założeniach teoretycznych (Janus-Sitarz 2009, 140205), wymagałyby obszernego studium, ujmującego refleksję fundowaną na analizie tak programów, jak i podręczników szkolnych, a także obserwacji praktyki lekcyjnej.

\section{Swobodne wypowiedzi uczniów - funkcja i znaczenie}

Rozmowa z uczniami o przeczytanym utworze, odsłuchanym nagraniu, obejrzanych materiałach ikonicznych czy audiowizualnych to powszechnie znane rozwiązanie dydaktyczne. Bywa ono traktowane jako forma diagnostyczna, sprawdzająca odbiór tekstu, sondująca wstępny poziom refleksji uczniów, określająca obszary ich zainteresowań. Działanie to ma swe fundamenty w tradycji dydaktycznej. W Analizie dzieła literackiego $w$ szkole Władysław Szyszkowski akcentował znaczenie pierwszych wrażeń recepcyjnych i zalecał „pozostawienie uczniom jak największej swobody w pierwszym zetknięciu z tekstem literackim oraz zapewnienie im nie krępowanej wymiany zdań na temat przeczytanego utworu" (Szyszkowski 1958, 18). Szyszkowski doceniał znaczenie samodzielnego myślenia uczniów i możliwości jego wyrażenia w sposób spontaniczny, jeszcze bez ingerencji nauczyciela. Pedagogiczne wyczucie znakomitego dydaktyka i potrzeba emancypacji uczniowskiej podmiotowości pozwala myśleć o swobodnych wypowiedziach uczniowskich poważniej niźli tylko jako elemencie diagnozującym. Można je potraktować jako punkt wyjścia do zaprojektowania cyklu lekcji poświęconych opracowaniu lektury na podstawie wskazanych przez uczniów problemów i zagadnień, uzupełnionego o kwestie istotne dla 
nauczyciela, respektujące jego zobowiązania przedmiotowe. Mogą one być także - realizując powyższe zadania - drogą do uczniowskich rozpoznań aksjologicznych.

\section{Aksjologia w świetle swobodnych wypowiedzi uczniów - ujęcie teo- retyczne i model zajęć}

W praktyce nauczycielskiej na swobodne wypowiedzi uczniów przeznaczałem z reguły całą godzinę lekcyjną. Przyświecała temu myśl o pobudzeniu motywacji uczniów, docenieniu ich pierwszego spojrzenia na przeczytane dzieło, autentyczne potraktowanie ich podmiotowości. Uczniowie szybko oswajali się z tego typu formą kontaktu z czytanym tekstem. Doceniali wartość takich zajęć, a przyzwyczajeni do poważnego traktowania ich sądów, mając świadomość swego wpływu na późniejsze opracowania dzieła, wypowiadali się chętnie, w poczuciu bezpieczeństwa, co oczywiście nie wykluczało pojawiania się dyskusji już na wstępnym etapie rozmowy o utworze.

Przyjęcie scharakteryzowanej wyżej drogi postępowania nie odbierało prowadzonym lekcjom ram strukturalnych. Wieloletnie doświadczenie pozwoliło mi wypracować określony, wariantowy model zajęć.

\section{Faza wstępna (ogniwo wprowadzające)}

Wariant I. Wypowiedzi uczniów wywołane wolnością, którą pozostawia im nauczyciel.

Uczniowie mogą zabrać głos w dowolnej kwestii. Ich uwagi koncentrować się mogą zarówno wokół oceny utworu (ważne, aby nauczyciel prosił o ich uzasadnienie), jego kompozycji, warstwy fabularnej, ale także wartości, których odbicie można odnaleźć w tekście. Zadaniem nauczyciela jest porządkowanie wypowiedzi. Istotne, by zwracał uwagę na to, że głosy uczniów dotyczą rozmaitych aspektów odbioru dzieła. Dobrze byłoby, aby już w tej fazie zajęć zezwolić uczniom na odnoszenie się do własnych wypowiedzi. Tę cześć warto zamknąć komentarzem podsumowującym. Faza ta powinna trwać od dziesięciu do piętnastu minut.

Wariant II. Pracę zaczynamy od ćwiczenia pisemnego.

Uczniom można przedstawić kilka schematów wypowiedzi, które wymagają uzupełnienia oraz dopełnienia kilkoma dodatkowymi zdaniami. Schematy mogą mieć następujący kształt:

Lektura podobała się mi, gdyż...

Lektura nie podobała się mi, gdyż...

Tekst uznaje za interesujący, gdyż...

Tekst nie wzbudził mojego zainteresowania, gdyż...

Mam co do tekstu mieszane uczucia, gdyż...

Tekst mnie zachwycit, ponieważ...

Tekst mnie rozczarował, ponieważ...

$W$ utworze zainteresował/zainteresowała/zainteresowało mnie przede wszystkim... Utwór wydaje się dla mnie ważny, gdyż... 
Zadaniem uczniów byłoby wybranie najbliższego im schematu (ewentualnie dwóch) i stworzenie w odniesieniu do niego pisemnej wypowiedzi, która będzie stanowiła pierwsze świadectwo odbioru. Odczytanie powinno znów być uzupełnione komentarzem nauczyciela. Można także w tej fazie zajęć, po wysłuchaniu np. dwóch bardzo różnych opinii, dopuścić uczniów do pierwszych konfrontacji.

Tę wstępną fazę lekcji (niezależnie od wariantu) może dopełniać skrótowa notatka powstająca na tablicy. Mogą ją tworzyć słowa-klucze, które nauczyciel zapisywałby na tablicy podczas słuchania wypowiedzi uczniów. Praca mogłaby się dokonywać na bieżąco, wraz z poszczególnymi wypowiedziami, ale również zamykać to ogniwo lekcji. W drugim wypadku lepiej byłoby, aby wyodrębnienie słów-kluczy odbyło się z aktywnym udziałem uczniów. Zapowiedź tego rozwiązania niewątpliwie wpłynęłaby na zwiększoną aktywność młodych ludzi podczas słuchania wypowiedzi rówieśników. Wstępne rozeznanie w uczniowskiej lekturze byłoby również pierwszym sygnałem aksjologicznego widzenia rzeczy - tak estetycznej oceny wartości dzieła, jak i dostrzegania w nim np. wartości moralnych, ujawniających się na różnych poziomach organizacji tekstu.

\section{Faza zasadnicza (ogniwo rozwijające)}

Ma ona najistotniejsze znaczenie zarówno ze względu na diagnozę odbioru, jak i identyfikację rozpoznań aksjologicznych uczniów. Jeżeli faza wstępna lekcji zamknęła się wyznaczeniem słów-kluczy, wówczas one mogą ukierunkować tę cześć zajęć - być punktem wyjścia do odczucia, a potem nazwania najważniejszych problemów i zagadnień ujawniających się w uczniowskim odbiorze lektury. Ważne jest, aby wskazując tematy warte refleksji, poddawać je próbie problematyzowania. Nie wystarczałoby jedynie ich wymienienie. Konieczne byłoby nazwanie złożoności dostrzeganych przez uczniów kwestii. Przykładowo w odniesieniu do utworu Ernesta Hemingwaya Stary człowiek i morze niewystarczające byłoby zaznaczenie, iż dzieło traktuje o starości czy przyjaźni. Chodziłoby o to, by uczniowie dostrzegli zmagania rybaka Santiago z ograniczeniami jego wieku, powiązali je z motywacjami bohatera czy próbami przekraczania siebie. Aby wstępnie, sygnalizując zagadnienie przyjaźni, wiązali je tak z wiekiem starego rybaka, jak i Manolina, wskazywali na ciężar, ale i niezwykłość tej relacji. Warto pierwsze myśli uczniów od razu skrótowo zapisywać na tablicy, a potem, po próbach pogłębienia, zapisywać je w postaci noszącej ślad klasowych ustaleń. Można owe zapisy pogrupować według wcześniej ustalonych kryteriów. Po zanotowaniu problemów uznanych za ważne przez większość zespołu klasowego całość warto uzupełnić chociażby o kilka uwag indywidualnych.

\section{Faza końcowa (ogniwo końcowe - zamykające)}

Ma ona dwa etapy realizacji. Pierwszym jest refleksja nauczyciela na temat tego, co udało się mu ustalić z klasą w ogniwach wstępnym oraz zasadniczym. Wskazane wyżej problemy dostrzeżone przez uczniów może 
on uzupełnić o sugestie niepojawiające się wcześniej, a które polonista uważa za istotne. Może odwołać się do ustaleń literaturoznawców. Kwestie te warto dopisać (np. odmiennym kolorem) do notatek lekcyjnych. Drugim i ostatnim etapem zajęć jest wypowiedź pisemna lub ustna uczniów, którzy mają z ustalonej listy problemów wybrać jeden lub dwa, które najchętniej omówiliby na lekcjach. Koniecznie wybór ten musi być wsparty uzasadnieniem. Tak zgromadzony materiał puentujący zajęcia może być punktem wyjścia do projektowania kolejnych zajęć, egzemplifikacją rozpoznań świata wartości ukazanego w utworze oraz świadomości aksjologicznej uczniów.

\section{Swobodne wypowiedzi uczniów jako droga do identyfikacji aksjolo- gicznych - materiał egzemplifikacyjny}

Lata pracy w szkole na różnych poziomach, ale szczególnie w gimnazjum, pozwoliły mi zgromadzić obfity materiał egzemplifikujący rozpoznania aksjologiczne uczniów ujawniające się w swobodnych wypowiedziach poprzedzających opracowanie lektury. Zaprezentowany niżej materiał pochodzi z rozpoznań dokonywanych $\mathrm{w}$ klasach gimnazjalnych, a więc u młodych ludzi w specyficznym momencie ich życia, gdy zazwyczaj wartościuje się w sposób bardzo wyraźny i skrajny, dokonuje deklaracji aksjologicznych ze względu na siebie, konieczność określenia własnej tożsamości, ukształtowania hierarchii swych potrzeb i celów. Punktem odniesienia dla zaprezentowanych $\mathrm{w}$ artykule wypowiedzi uczniów były następujące dzieła: Stary człowiek i morze Ernesta Hemingwaya, Córka czarownic Doroty Terakowskiej oraz oparty na Iliadzie Homera film Wolfganga Petersena pod tytułem Troja. Pierwszy z wymienionych tekstów to klasyka literacka, drugi, chociaż znacznie nowszy, stanowi ważną pozycję w polskiej literaturze dla dzieci i młodzieży. Wymieniony film wykorzystuję jako materiał przybliżający młodzieży epos Homera, ale omawiam jako dzieło autonomiczne, wpisujące się w kulturową refleksję nad archetypem herosa (Achilles) bądź bohatera ojczyzny (Hektor).

\section{Stary człowiek i morze}

Tekst Hemingwaya omawiałem zazwyczaj w drugiej klasie gimnazjalnej, w obrębie szerszego tematu mierzenia się ludzi z losem. Uczniowie przyzwyczajeni do pracy z podręcznikami To lubię!, a zatem postrzegający literaturę jako pewną formę złożonej opowieści o życiu człowieka, zawsze akcentowali potencjał aksjologiczny utworu amerykańskiego pisarza. $\mathrm{Na}$ poziomie rozważań wstępnych zazwyczaj zwracali uwagę na nużącą narrację, tempo opowieści, niewielką liczbę dziejący się zdarzeń, ale podkreślali, że mają poczucie, iż tekst mówi o czymś ważnym, zwracali uwagę na głównego bohatera, jego postawę, próbując od razu nazywać cechy bohatera.

Przeczytałam. Było to krótkie, ale czytałam długo. Całość bardzo się dłużyła. Miałam wrażenie, że nic się nie działo. Ale warto to było przeczytać. Coś w tym było wartościowego. Santiago był twardy, uparty, niezniszczalny, chociaż już stary.

/Gabrysia, lat 14/ 
Takie to było nijakie. Nie czytało się mi dobrze, ale sam Santiago w porządku. Taki jakiś ciepły. I fajnie ukazane jego relacje z chłopcem. To było najlepsze.

/Ania, lat 14/

Całość można byłoby skrócić o dwie trzecie. Wtedy miałoby się wrażenie, że w tekście więcej się dzieje. Ale przeczytałem z zainteresowaniem. Zaskoczył mnie koniec. Myślałem, że uda mu [Santiago] się dowieźć rybę. To zakończenie nie było kiczowate.

/Mateusz, lat 14/

Podane przykłady wskazują, że już wstępne rozeznania aksjologiczne, chociaż nie wprost, dają obraz wartości, które wpisane są w postawę starego rybaka. Co ciekawe, próba spojrzenia na bohatera łączy się z oceną artystycznej jakości, „wykonania” utworu. Nie zawsze jednak ideowa wartość dzieła autora Komu bije dzwon przyjmowana bywa bez kontrowersji. Oto jak jedna z uczennic przedstawiła swą wstępną refleksję:

Wiem, że jest to ważny utwór. I to, o co w nim chodzi, jest ważne. Ten jego [rybaka] upór, niezłomność, walka z losem i to, że się nie poddaje. Tak się pisze o Starym człowieku... Ale dla mnie w tym nie ma nic nowego, czego nie wiedziałabym wcześniej, o czym bym nie czytała w innych książkach. Znacznie lepszych, ciekawszych, nie tak nudnych jak ta.

/Natalia, lat 14/

Dodać trzeba, że powyższe słowa wypowiadała dziewczynka bardzo oczytana, świetnie radząca sobie z przedmiotem, ale i bezkompromisowa, umiejąca wyraźnie zaznaczyć swe zdanie. Co jednak ważne, wypowiedź ta (wywołująca słowa uznania i aprobatę wielu innych koleżanek), zdradza postrzeganie literatury czy szerzej - kultury, jako pewnej mozaiki znaczeń, powtarzających się motywów. Uczennica, rozpoznając u Hemingwaya to, co dla niej znane, dosyć swobodnie potraktowała sprawę oryginalności. Wydaje się jednak, że jest to typowe dla wieku gimnazjalnego.

Faza zasadnicza lekcji o utworze Hemingwaya, po wstępnych refleksjach uczniowskich, w zasadzie za każdym razem spełniała swoje zadanie tak jeżeli chodzi o diagnozę, jak i identyfikacje intuicyjnych rozpoznań ${ }^{2}$. Każdorazowo uczniowie za najważniejsze zagadnienia wpisane w lekturę uznawali (1) walkę rybaka z marlinem i samym sobą, własną starością, (2) kwestię samotności starca i równocześnie jego przyjaźni z Manolinem, (3) zagadnienie losu, z którym zmaga się Santiago oraz (4) wyjątkowy obraz miłości rybaka do morza i świata natury. Czasami zwracali także uwagę na (5) zagadnienie relacji społecznych w ukazanej przez pisarza wiosce, (6) zasygnalizowane tylko w tekście kwestie rodzinne. Praca nad tekstem autora Pożegnania $z$ broniq czasami przynosiła też rozmaite niespodzianki. Od czasu do czasu pojawiały się bowiem zagadnienia bardzo oryginalne, np. obraz kontaktów między Kubą a Stanami Zjednoczonymi czy wielkich sportowców czasów Hemingwaya. Chociaż były one bardzo swobodnie związane

\footnotetext{
${ }^{2}$ Należy mieć świadomość, że nie zawsze można w tym wypadku mówić o odbiorze intuicyjnym. Zdarza się, że przed pierwszą lekcją z lektury uczniowie przedyskutowali tekst z rodzicami lub starszym rodzeństwem bądź skorzystali z rozmaitych opracowań.
} 
z opowieścią amerykańskiego prozaika, również znalazły się w orbicie zainteresowań pojedynczych uczniów w specyficzny sposób konkretyzujących lekturę. Zakończenie tak prowadzonych zajęć warto dopełnić informacjami biograficznymi, które mogą wskazywać na genezę utworu oraz dodatkowe tropy interpretacyjne potrzebne na dalszych lekcjach „z lektury”3.

\section{Córka czarownic}

Wstępne wypowiedzi uczniów ujawniły dosyć podobny sposób waloryzowania powieści, jak było to w przypadku dzieła Hemingwaya, chociaż zasadniczo w mniejszym stopniu służyły eksponowaniu samej aksjologii możliwej od odczytania z utworu. Ujawniały także rozmaite wątpliwości co do typu i wartości lektury. Oto przykłady:

Książka średnio mi się podobała. Ta lektura była dziecinna. Trochę jak bajka, baśń. Nie lubię takiej lektury, chociaż chyba nie była to książka tylko dla dzieci.

/Julia, lat 13/

Niejednoznacznie oceniam książkę. Fabuła była typowa dla fantasy. Ale czytało mi się dobrze, szybko. Ciekawy był motyw z czarownicami. Dobrze była też pokazana sprawa pustyni. Rozczarowało mnie zakończenie. Terakowska go urwała, zamknęła na dwóch stronach.

/Ania, lat 14/

Niewiele mnie w powieści zdziwiło. To typowa książka o dojrzewaniu, tyle że w klimacie fantasy. Dobrze pisarka pokazała to, jak Luelle się zmienia, walczy ze sobą, uczy się bycia władcą. Szkoda, że ten wątek z Ajokiem tak dziwnie się skończył.

/Natalia, lat 14/

W odniesieniu do wstępnej fazy lekcji stwierdzić trzeba, że Córka czarownic bardziej niż tekst Hemingwaya inspiruje uczniów do podejmowania rozmów na temat walorów artystycznych dzieła, kwestii wartości estetycznych. Może to wynikać z ambiwalentnego odbioru lektury. Zwykle część uczniów krytykuje powieść za wtórność i powtarzalność tego, co można odnaleźć w literaturze fantasy czy w powieściach dla dzieci i młodzieży. Są jednak zawsze osoby, które wskazują na dwuadresowość lektury, mają poczucie, że za fabułą skrywają się wcale nie dziecinne problemy. Druga faza pracy nad powieścią Terakowskiej przynosi także dowód na to, że kilkunastoletni uczniowie dostrzegają złożone kwestie, które przynosi utwór. Oto najczęściej wskazywane sprawy: (1) powtarzające się losy wielkich imperiów; (2) obraz społeczeństwa w podbitym i okupowanym kraju; (3) problem władzy i związane z nim cechy władcy; 4) dorastanie i dojrzewanie do bycia nie tylko władca, ale i wartościowym człowiekiem. Jako egzemplifikacja myślenia uczniów niech posłużą przykładowe wypowiedzi:

Najważniejsze wydaje mi się to, jakie cechy ma mieć władca, co znaczy być dobrym [władcą]. Zwłaszcza gdy chodzi o jego sposób myślenia o poddanych, ludziach.

/Michał, lat 14/

Proponuję skorzystać ze zbioru szkiców poświęconych amerykańskiemu prozaikowi: Hemingway w oczach krytyki światowej, 1968, Rzeczkowski H. (red.), Warszawa (tu ciekawy może być np. tekst C. Bakera, Sędziwy marynarz, przeł. J. Strzetelski). 
W powieści widać analogię do losów starożytnego Rzymu. Jego rozkwitu i upadku. I nie tylko. Terakowska pokazuje to, jakie są koleje potężnych mocarstw, które są wielkie, a potem upadają.

/Ola, lat 15/

Wskazane wyżej problemy warto uzupełnić w zakończeniu lekcji zasygnalizowaniem obecności w utworze przestrzeni archetypowych (np. Lasu, Miasta, Wsi, Pustyni...), które są ugruntowane w kulturze oraz występują w powieści autorki Poczwarki jako nośniki rozmaitych znaczeń. Kluczowym także jest zwrócenie uwagi na rolę i znaczenie twórczości, która ma moc opierania się złu, jest elementem przetrwania tożsamości narodowej. Warto także podpowiedzieć specyficzny kontekst biograficzny i historyczny, który rzuca światło na genezę omawianego tekstu (Nowak 2005, 25, Baluch 1998, 76) ${ }^{4}$.

\section{Troja}

Rozmowa o filmie poprzedzona zostaje wstępnym rozpoznaniem przyczyn wojny trojańskiej (na podstawie mitów) oraz postaci, które związane są z opowieścią Homera. Taka prezentacja powoduje, że postaci eposu konkretyzują się uczniom w filmowym dziele Petersena. Wywołuje to emocjonalne związanie uczniów z bohaterami historii, a hollywoodzki rozmach produkcji sprzyja wyraźnemu wartościowaniu.

Zasadniczo wstępne swobodne wypowiedzi uczniów każdorazowo pozytywnie opisują Troję. Młodzi ludzie dają się uwieść epickiej historii przeniesionej na ekran, poddają się magii największych gwiazd kina z Bradem Pittem na czele. Zwracają zazwyczaj uwagę na widowiskowość scen, przepiękne kostiumy i scenografię, wyraziste postaci. Pod wpływem informacji zamieszczonych na portalu Filmweb jako wady wskazują fakt niewyraźnego ukazania upływu czasu oraz specyficzną kolorystykę zastosowaną w produkcji. Dziewczyny dosyć często eksponują ładne ukazanie wątku miłosnego Achillesa i Bryzeidy, a także zazwyczaj dosyć wyraźnie dystansują się od licznych scen krwawych, które dla chłopców są zwykle zaletą ich zdaniem wpływają na urealnienie obrazu wojny, podkreślają, że jest ona okrutna. W fazie wstępnej zajęć częściej pojawiają się uwagi o artystycznej stronie filmu. Wypowiedzi uczniów kierują się w stronę tworzywa, warsztatu reżyserskiego czy aktorskiego. Podyktowane to może być myśleniem o późniejszym napisaniu recenzji filmu.

Dopiero faza zasadnicza (ogniwo rozwijające) zajęć ujawnia aksjologiczny potencjał filmu. Wówczas omówić można problem rozmaitych kategorii wartości: moralnych (etycznych), religijnych, a także witalnych czy materialnych. Dla przykładu podaję kilka wypowiedzi, które ilustrują wspomnianą wyżej tendencję:

${ }^{4}$ Powstanie książki zbiegło się ze śmiercią matki pisarki, co niewątpliwie wpłynęło na patetyczny i podniosły charakter narracji. Utwór ostatecznie kształtował się w czasie stanu wojennego. Bezkrwawy przewrót zamykający ukazane przez Terakowską rządy Najeźdźców wydaje się korespondować z aktualną sytuacją społeczną i polityczną Polski. Pisze o tym Alicja Baluch. 
Bardzo mi się podobał Agamemnon [śmiech klasy] ${ }^{5}$. Był tak zły, że jak się tylko pokazywał, to było widać, że jest straszny. I reżyser pokazał, inaczej niż było w micie, że zależało mu [Agamemnonowi] tylko na bogactwach Troi, a nie na bracie i Helenie. /Julia, lat 13/

Film mówi o słabości religii. Nie mogłem już znieść tego starego dziada Priama. Jak można być tak naiwnym? Wszyscy mówili mu, że ten koń jest podejrzany, że to jakiś podstęp, a on się uparł, by go wprowadzić do Troi. Tu nawet Parys był od niego mądrzejszy.

/Maciej, lat 13/

Najlepszy był Hektor. On walczył o coś, o ojczyznę. Pokazywał sobą patriotyzm. Bana [aktor odtwarzający rolę herosa] był genialny. Wchodził w kamerę i to był ktoś. Szlachetny, dzielny, no i sto razy mądrzejszy od brata. Ten był beznadziejny. Najbardziej mi było szkoda tego, że zginął [Hektor].

/Piotrek, lat 13/

Powyższe głosy pojawiały się na tle głównych rozpoznań problemów, które zdaniem uczniów wywoływał film. Doświadczenia pokazują, że na podstawie produkcji Petersena uczniowie łatwo potrafią wskazać skrajne wartości, za które walczą bohaterowie, dostrzegają ukazaną przez reżysera rolę miłości w życiu Achillesa czy różne cele ludzi, których losy zbiegły się pod murami Ilium. W wypowiedziach widać podziw, akceptację, wątpliwości, a czasem nawet pogardę. Problemy, które dostrzegają uczniowie w omawianej produkcji filmowej, wiążą się z zagadnieniem wartości. Uczniowie najczęściej proponowali do opracowania następujące kwestie: (1) cele, za które ludzie są gotowi walczyć i ginąć; (2) odpowiedzialność za ojczyznę, życie własne i szczęście rodziny/kraju; (3) miłość i wojna a postawy głównych bohaterów dzieła; (4) znaczenie religii i wiary. W fazie końcowej zajęć warto wskazać potencjał myślowy tych zagadnień i odnieść się do opracowań historycznych czy literaturoznawczych.

\section{Kilka wniosków końcowych}

Swobodne wypowiedzi uczniowskie mają istotne znaczenie dla zorientowanej antropocentrycznie edukacji kulturowo-literackiej. Kształcą myślenie analityczne oraz umiejętność budowania syntez, wymagają dbałości o precyzję wypowiedzi w mowie i piśmie, uczą sztuki dyskutowania, otwierają na interakcje wewnątrz zespołu klasowego. Umożliwiają jednak przede wszystkim identyfikację uczniowskich sposobów wartościowań, pozwalają nastolatkom na określanie siebie wobec innych w aksjologicznej przestrzeni wyznaczonej lekcyjną rozmową i potencjałem semantycznym przeczytanej lektury czy poznanego tekstu kultury. Tym samym są ważnym elementem na drodze uczniów do dojrzałości myślowej i emocjonalnej, mają niebagatelne znaczenie dla ich rozwoju osobowościowego w sferze wartości. Dla nauczyciela, oprócz realizacji celów wynikających z zobowiązań

${ }^{5}$ Wszelkie dopiski w wypowiedziach uczniów w nawiasach pochodzą od autora artykułu. 
przedmiotu, mogą być szkołą myślenia podmiotowego o uczniach, punktem wyjścia dla aksjologicznego projektowania lektury, wyzwalającym pokłady twórczego myślenia, potrzebę doskonalenia warsztatu nauczycielskiego. Mogą być także materiałem diagnozującym zmiany w myśleniu i wartościowaniu młodych ludzi, które - pod wpływem czynników cywilizacyjnych czy społeczno-kulturowych - ulegają rozmaitym modyfikacjom. Tendencje te dokumentują zebrane i przedstawione wyżej wypowiedzi uczniów, które mogą w jakimś stopniu otwierać na dyskusję nad tym, jak zmienia się myślenie i wartościowanie uczniów.

\section{Bibliografia}

Baker Carlos, 1968, Sędziwy marynarz, Strzetelski J. (przeł.), w: Krzeczkowski H. (red.) Hemingway w oczach krytyki światowej, Warszawa.

Baluch Alicja, 1998, Wokół tematu spełnienia w „Córce czarownic” Doroty Terakowskiej, w: Ceremonie literackie, Kraków.

Denek Kazimierz, 2000, Aksjologiczne aspekty edukacji szkolnej, Toruń.

Hemingway w oczach krytyki światowej, 1968, Krzeczkowski H. (red.), Warszawa.

Janus-Sitarz Anna, 2009, Przyjemność i odpowiedzialność w lekturze, Kraków.

Jedliński Ryszard, 2000, Językowy obraz świata wartości uczniów kończących szkołę podstawowa, Kraków.

Jędrychowska Maria, 2002, Zapis projektu zadań formacyjnych edukacji polonistycznej w strukturze podręcznika szkolnego, w: Kosętka H., Uryga Z. (red.), Podręcznik jako narzędzie kształcenia polonistycznego w gimnazjum, Kraków.

Karwatowska Małgorzata, 2012, Autorytet $w$ opiniach młodzieży, Lublin.

Kleszcz Magdalena, Łączyk Małgorzata, 2014, Młodziė̇ licealna wobec wartości, samotności i pasji, Kraków.

Nowak T. Katarzyna, 2005, Moja mama czarownica, Kraków.

Sporek Paweł, 2016, Przestrzeń aksjologiczna w wybranych podręcznikach gimnazjalnych do kształcenia literacko-kulturowego (1999 - 2005), Kraków.

Szymański Mirosław, 1998, Młodzież wobec wartości. Próba diagnozy, Warszawa.

Szyszkowski Władysław, 1958, Analiza dzieła literackiego w szkole, Warszawa.

Świda-Ziemba Hanna, 2005, Młodzi w nowym świecie, Warszawa.

Świda-Ziemba Hanna, 1998, Wartości egzystencjalne młodzieży lat dziewięćdziesiątych, Warszawa.

Wagner Iwona, 2005, Stałość czy zmienność autorytetów. Pedagogicznospołeczne studium funkcjonowania i degradacji autorytetów w zmieniajacym się społeczeństwie, Kraków. 


\section{O Autorze:}

Paweł Sporek - dr, adiunkt w Katedrze Dydaktyki Literatury i Języka Polskiego Instytutu Filologii Polskiej Uniwersytetu Pedagogicznego w Krakowie; autor książek: Przestrzeń aksjologiczna $w$ wybranych podręcznikach gimnazjalnych do kształcenia literacko-kulturowego (19992005), W stronę lektury. Propozycje tekstów do opracowania lekcyjnego dla uczniów szkół podstawowych oraz gimnazjów oraz licznych artykułów z zakresu dydaktyki i metodyki nauczania języka polskiego, współredaktor monografii Powrót do ojczyzny? Patriotyzm wobec wyzwań nowych czasów. Kontynuacje i nawiazania; w latach 2007-2008 sekretarz redakcji czasopisma metodycznego „Nowa Polszczyzna”; nauczyciel szkoły podstawowej, gimnazjum, liceum, prowadził zajęcia $\mathrm{w}$ ramach kształcenia dorosłych; obecnie pracuje w krakowskim Prywatnym Gimnazjum Akademickim nr 6. 